\title{
Diagnóstico ambiental da área de preservação permanente da nascente do córrego almeida utilizando ferramenta de geoprocessamento (Aparecida de Goiânia - GO)
}

\author{
Environmental diagnosis of conservation area permanent stream of spring almeida using \\ gis tool (Aparecida de Goiânia - Goias - Brazil)

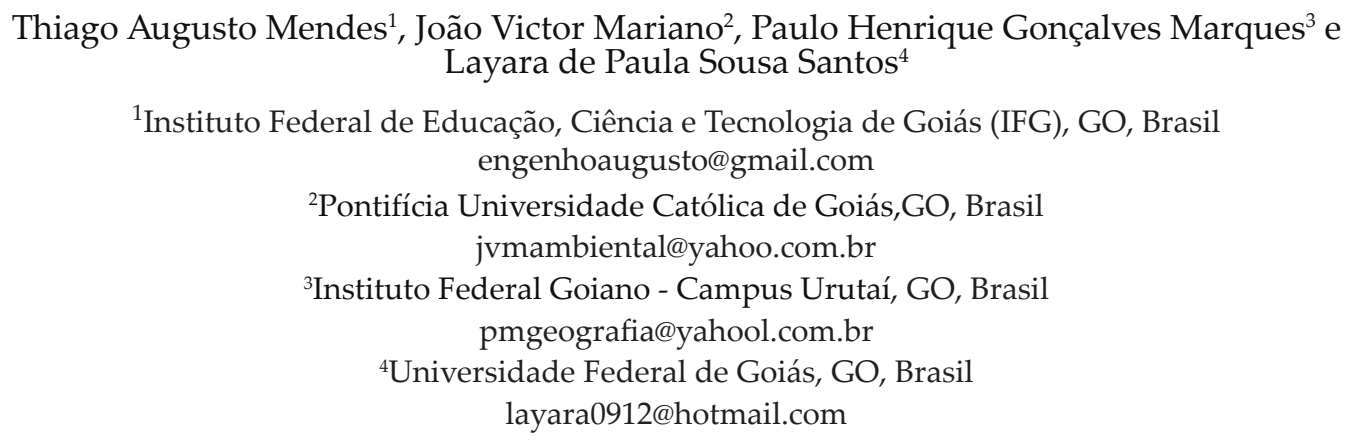

\begin{abstract}
Resumo
Na maioria das cidades brasileiras, especialmente nas metrópoles, as ocupações urbanas afetam e até são instaladas em áreas de preservação permanente (APP). Como consequência dessas ocupações inapropriadas, surgem inúmeros impactos ambientais como: erosões, alagamentos e contaminação de corpos hídricos. Neste contexto foi realizado diagnóstico ambiental da APP referente a uma das nascentes do Córrego Almeida, situada no Bairro Jardim Luz, município de Aparecida de Goiânia (GO), a fim de avaliar os impactos ambientais provocados pelas ações humanas à microbacia em questão e sugerir possíveis medidas mitigadoras para posterior recuperação ambiental. Durante vistorias in loco foi constatada a existência de erosão, possivelmente ocasionada pela má execução dos serviços de pavimentação e drenagem urbana das ruas adjacentes e ocupação e uso do solo impróprio em alguns locais. Para a avaliação da susceptibilidade à erosão e do potencial erosivo do solo da área estudada, utilizou-se a metodologia do Instituto de Pesquisas Tecnológicas de São Paulo (IPT). A prática desta metodologia tornou possível a elaboração e apresentação do Mapa de Potencialidade à Erosão Laminar da APP podendo-se constatar que aproximadamente $23 \%$ da área analisada possui alta potencialidade à erosão e está mais próxima à nascente e às vias urbanas.
\end{abstract}

Palavras-chave: Ocupações Urbanas; Microbacia; Erosão.

\begin{abstract}
In most Brazilian cities, especially in cities, urban occupations affect and are even installed in permanent preservation areas $(A P P)$. As a result of these inappropriate occupations, there are numerous environmental impacts such as erosion, flooding and contamination of water bodies. In this context it was conducted environmental assessment of APP related to one of the headwaters of the stream Almeida, located in Jardim Luz, Aparecida de Goiânia (GO), in order to assess the environmental impacts of human actions on the watershed in question and suggest possible mitigating measures to further environmental recovery. During inspections in loco was found to contain erosion, possibly caused by poor execution of paving services and urban drainage of adjacent streets and occupation and use of unsuitable soil in some locations. For the evaluation of susceptibility to erosion and potential erosion of soil under study, we used the methodology of the Institute for Technological Research of São Paulo (IPT). The practice of this methodology made possible the preparation and presentation of Potential Map of the Laminar Erosion of APP can be seen that approximately 23\% of the analyzed area has high potential for erosion and is closer to the source and urban roads.
\end{abstract}




\section{Introdução}

A ocupação urbana no Brasil quase sempre é caracterizada por ausência de planejamento e consequentemente destruição dos recursos naturais, em particular córregos e florestas. No entanto, esse processo causa crescimento desordenado de domicílios urbanos em áreas que deveriam ser preservadas para manter o equilíbrio ecológico e hidrológico de uma microbacia (SANTANA, 2011).

Diante disso, as consequências deste processo inadequado são: falta de condições sanitárias mínimas, ausência de serviços indispensáveis à vida saudável, ocupação de áreas inadequadas, destruição de recursos ambientais de valor ecológico, poluição do meio ambiente e habitações em condições precárias (MOTA, 2003).

A grande expansão urbana do município de Aparecida de Goiânia, com desmatamento excessivo, presença de grandes áreas impermeabilizadas por asfalto e concentração populacional com forte verticalização de edifícios provocaram o aumento de degradações (MARQUES, 2006). Assim, o crescimento acelerado e desordenado desse município gerou inúmeros problemas, dentre os quais se destaca os processos erosivos relacionados à ocupação de fundos de vale e poluição dos recursos hídricos.

Segundo IBGE (2014), o município de Aparecida de Goiânia possui 511.323 habitantes, é marcado pelo intenso incremento populacional, principalmente desde a década de 90 , causando uma concentração dos espaços urbanos, refletida na verticalização da região central e norte da cidade. Pertencente à microrregião homônima e fazendo parte da mesorregião Centro Goiana, a cidade de Aparecida de Goiânia gera um processo de conurbação com a cidade de Goiânia, como é o caso da parte norte, por isso é alvo de grandes impactos ambientais negativos (Figura 1).

Moreira (1992) define impacto ambiental como qualquer alteração no meio ambiente em um ou mais de seus componentes provocados por ação humana. De acordo com a Norma Brasileira de Regulamentação (NBR) ISO 14.001/2004, impacto ambiental é qualquer modificação do meio ambiente, adversa ou benéfica, no todo e ou em parte, das atividades e produtos ou serviços de uma organização, podendo ainda ser interpretado por degradação da qualidade ambiental de uma determinada área.

Um tipo de impacto ambiental que merece destaque é a erosão. A erosão é um processo que se traduz na desagregação, transporte e deposição de material do solo, subsolo e rocha em decomposição, pelas águas, ventos ou geleiras. A erosão inicia-se na parte superficial, aprofundando-se até encontrar a rocha viva. Portanto, o processo erosivo provoca o rebaixamento dos horizontes (CONCIANI, 2008).

Quanto ao tipo de agente causador, a erosão pode ser classifica em eólica ou hídrica. A erosão eólica consiste no transporte de partículas de solo pela ação do vento, apresentando maior importância nas regiões planas com baixa precipitação, alta incidência de ventos e pouca vegetação para proteger o solo (PRUSKI, 2009). Segundo Ashman e Puri (2002) o problema da erosão não é apenas diminuir a quantidade de nutrientes no topo do solo, mas também causa assoreamento e poluição nos lugares em que os sedimentos se depositam.

As principais causas da erosão, de acordo com Wild (1993) são: desmatamentos; agricultura e pecuária sem adoção de práticas conservacionistas; cultivo e pecuária em encostas de elevada declividade; trilhas abertas por animais e por homens compactando os solos por onde

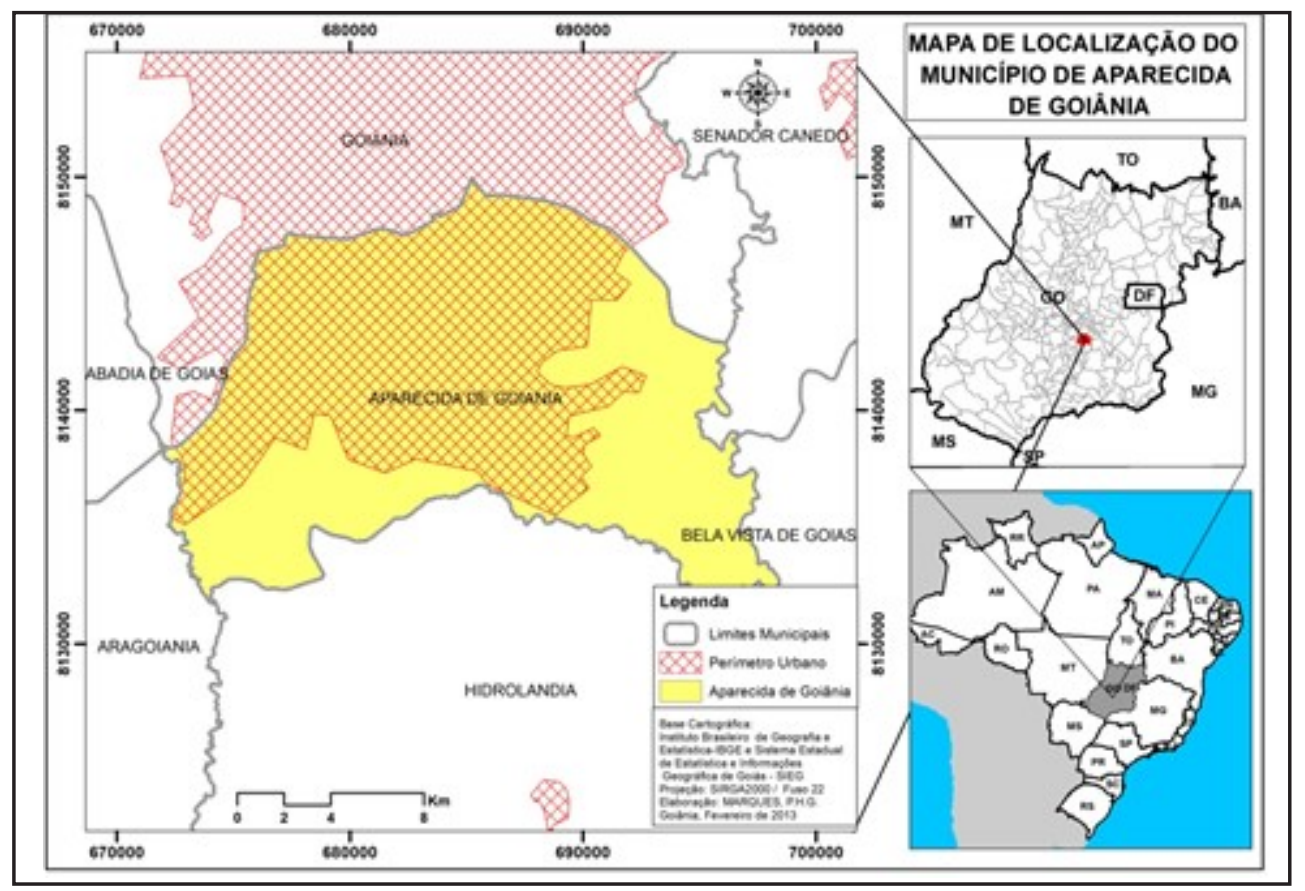

Figura1 - Mapa de localização do município de Aparecida de Goiânia 
a água se escoa com facilidade; construção de rodovias sem cuidados especiais, o que faz aumentar o escoamento superficial causando ravinas que podem evoluir para voçorocas; mineração e outras atividades econômicas que deixam os solos desprotegidos, sem recuperação dessas áreas após o término dessas atividades.

As principais formas de erosão são: pluvial por arrastamento, laminar, linear, interna, marinha, fluvial e eólica. Pode-se considerar a erosão pluvial por arrastamento como uma decorrência lógica da erosão pluvial por impacto, pois as partículas de solo soltas e desagregadas por este tipo de erosão ficam em condições de ser facilmente carregadas (SEIXAS, 1984). A erosão laminar é caracterizada pela distribuição do desgaste em camadas de solo com profundidade relativamente uniforme e de área bastante extensa (SEIXAS, 1984). Conforme Infanti e Fornassari Filho (1998), a erosão linear é causada pela concentração das linhas de fluxo das águas de escoamento superficial, isto resulta em pequenas incisões nas superfícies do terreno, em forma de sulcos que podem evoluir, por aprofundamento, para ravinas.

A erosão marinha é causada pelo impacto das águas dos mares e oceanos sobre os solos e rochas da costa (CONCIANI, 2008). A erosão interna ocorre internamente ao maciço de solo, esta forma de erosão só é percebida na superfície quando existem subsidências (recalques) de grande magnitude devidas ao afundamento dos "canais" formados no solo (CONCIANI, 2008). Igualmente à força de arraste das águas de superfície, as águas dos rios retiram o solo das suas margens. Trata-se da erosão fluvial. Esta é mais acentuada em regiões acidentadas. Vem daí a importância da conservação das matas ciliares (CONCIANI, 2008).

Quanto à forma de desgaste as erosões lineares podem se classificar em sulcos, ravinas e voçorocas. Para Salomão (1998), os sulcos são considerados como pequenas incisões na superfície do solo, originados pela concentração de linhas de fluxo d'água de escoamento superficial, podendo evoluir e se transformar em ravina. Quando há um aumento nas dimensões das incisões no solo, que são causadas pela concentração das águas da chuva, a erosão passa a se chamar de erosão em ravinas (CONCIANI, 2008). As voçorocas consistem no último estágio do processo erosivo, são mais largas e mais profundas que os sulcos, transformando-se, muitas vezes, em características permanentes nas paisagens (GUERRA, 1999).

No que diz respeito à questão conceitual, dois termos tem sido empregados com frequência, indicando propriedades relativas à erosão: erodibilidade e erosividade. A erosividade da chuva e a erodibilidade do solo são dois importantes fatores físicos que afetam a magnitude da erosão do solo. Mesmo que a chuva, a declividade do terreno e a cobertura vegetal sejam as mesmas, alguns solos são mais susceptíveis ao destacamento e ao transporte de partículas pelos agentes de erosão que outros. Essa diferença, devido às propriedades do solo, é conhecida como erodibilidade do solo (CARVALHO et al., 2006). Segundo Lal e Elliot (1994) a erosividade é a expressão da habilidade dos agentes erosivos, como a água, que causa o destacamento e o transporte de solo. A quantificação destes dois fatores é importante na previsão da erosão e no planejamento do uso do solo. Entretanto, a erodibilidade dos solos tem sido o fator de maior interesse geotécnico.

Diante dos diversos agentes, tipos, características e peculiaridades das erosões, é importante avaliar como se processa e desenvolve os mecanismos erosivos. Como forma de diagnosticar o processo erosivo pode-se recorrer a ferramentas e softwares de geoprocessamento de imagens para sobreposição de mapas físicos, topográficos, hidrográficos e outros elementos que permitam identificar a potencialidade erosiva. Desse modo, a análise dos processos erosivos existentes na Área de Preservação Permanente (APP) da nascente em estudo foi realizada com o auxílio de mapas elaborados a partir de visitas em campo e imagens de satélites.

As Áreas de Preservação Permanentes (APP's) são de grande importância para a manutenção da qualidade dos recursos hídricos uma vez que atuam como barreiras para águas pluviais, aumentando a absorção da água no solo. Possui papel fundamental na composição de matéria orgânica, elemento essencial para fertilidade e agregação dos solos. Contribui ainda para a quantidade e qualidade das águas, aumentando a vazão em períodos secos, além de melhorar a qualidade do ar, com menores variações de temperatura e menores prejuízos a biota. Retém sedimentos do solo evitando o assoreamento e a turbidez do corpo d'água e colaboram significativamente para preservação de inúmeras espécies faunísticas e de ecossistemas inteiros (FRANCO, 2009). Portanto, são instrumentos de relevante interesse ambiental, integram o desenvolvimento sustentável com função ambiental de preservar os recursos hídricos, a paisagem, a estabilidade geológica, a biodiversidade, o fluxo gênico de fauna e flora, proteção do solo, além de assegurar o bem estar das populações humanas (CONAMA, 2002).

Nesse contexto, os mapas de uso do solo permitem a avaliação da forma como tem se dado o uso do solo e da cobertura vegetal em determinada região. São elaborados, entre outras formas, por meio de imagens de satélite e ferramentas de sensoriamento remoto que se portam como fonte de dados nos espaços temporais. Para isso, a escolha da imagem e da metodologia de classificação do uso do solo deve ocorrer de acordo com as necessidades do usuário e com as características da região (ALVES; COSTA, 2007).

Conforme Sousa et al. (2009), o mapa de declividade mostra o grau de inclinação do relevo em cada porção do espaço. Portanto, trata-se de dados apresentados de forma zonal, explicitando a porcentagem ou grau de inclinação por meio da relação entre a variação na altitude e a distância horizontal no terreno. De forma prática, a declividade influencia no transporte de ma- 
terial particulado de solo, acarretando maiores riscos de erosão em solos desprovidos de cobertura vegetal com elevadas declividades. No mapa hipsométrico são apresentadas, em faixas de intervalos numéricos, as altitudes do terreno em relação ao nível do mar. Com o auxílio deste tipo de mapa, é possível constatar a diferença de elevação entre porções do espaço na área de estudo, podendo-se inferir algumas características relacionadas à forma do relevo e ao modo como ocorre a drenagem fluvial (SOUSA et al., 2009).

Tratando-se do local de estudo, conforme Ação Civil Pública Ambiental movida pela $4^{\circ}$ Promotoria de Justiça de Aparecida de Goiânia, a prefeitura deste município realizou aterro parcial da APP da nascente do Córrego Almeida, localizada no Bairro Jardim Luz, para a ampliação e asfaltamento de ruas localizadas na parte superior da cabeceira do córrego. Esta ação possivelmente desencadeou o aumento do processo de escoamento superficial das águas da microbacia e consequentemente o processo erosivo na nascente e no leito do Córrego Almeida.

Desta forma, este trabalho objetiva-se no diagnóstico ambiental da área de preservação permanente referente a uma das nascentes do Córrego Almeida, situada no Bairro Jardim Luz, município de Aparecida de Goiânia (GO), provocados pelo processo de urbanização, bem como sugerir possíveis medidas mitigadoras para a recuperação ambiental.

\section{Materiais e métodos}

Este artigo teve como fundamento o método de diagnóstico ambiental, que visa à integração entre os diversos elementos que compõem a microbacia hidrográfica envolvida. O estudo divide-se em cinco etapas:

$\mathbf{1}^{\circ}$ - Diagnóstico ambiental com base na Lei $\mathrm{N}^{\circ}$ 005/2002, do município de Aparecida de Goiânia (GO), considerando as faixas bilaterais contíguas ao Córrego Almeida, com largura de 50 metros a partir das margens ou cota de inundação, e a área circundante da nascente deste mesmo córrego, com um raio de 100 metros;

$2^{\circ}$ - Elaboração de mapas do meio físico, com base no projeto Zoneamento Ecológico-Econômico da Área do Aglomerado Urbano de Goiânia, realizado pelo Instituto Brasileiro de Geografia e Estatística (IBGE, 1994), os quais permitiram analisar os impactos existentes na nascente em estudo. O mapeamento dos impactos, bem como a dinâmica da ocupação da nascente, foi realizado por meio de imagens do Google Earth, com resolução espacial de 60 centímetros. Em complementação ao trabalho foram realizadas quatro visitas em campo, sendo duas no mês de março/2015 e duas no mês de abril/2015, com o objetivo de observar as erosões e seu processo, bem como validar os tipos de impactos para representá-los nos materiais cartográficos. A correlação entre os diferentes mapas elaborados foi realizada por meio de ferramentas de transparência disponíveis no software ArcGis 9.3 ESRI.

$3^{\circ}$ - A superposição dos resultados obtidos a partir do diagnóstico ambiental e dos diversos mapas de meio físicos gerados possibilitou a aplicação do Mapa de Potencialidade à Erosão Laminar.

Para a avaliação da susceptibilidade à erosão e do potencial erosivo do terreno da área de estudo optou-se pela metodologia apresentada por Salomão (1992). A susceptibilidade à erosão em uma dada área pode ser avaliada com base no cruzamento ou interseção dos dados qualitativos de erodibilidade relativa dos solos com os dados quantitativos da inclinação das rampas representadas no terreno por faixas de declividade (Figura 2a).

Para a elaboração dos mapas de declividade e de hipsometria foi gerado um arquivo raster por meio de dados altimétricos fornecidos pelos produtos TOPODATA/INPE (2009). A declividade é representada em seis diferentes classes (Tabela 1). As seis classes definidas possibilitam qualificar o relevo de acordo com a inclinação da superfície em relação ao plano do horizonte

Com o mapa de susceptibilidade à erosão laminar elaborado o procedimento seguinte foi confeccionar o mapa de potencialidade à erosão laminar. A metodologia adotada baseia-se no cruzamento do mapa de susceptibilidade à erosão laminar com o mapa de cobertura vegetal e uso do solo. Tal procedimento foi baseado na metodologia do IPT (1991), a qual foi amplamente discutida por Salomão (1999) (Figura 2b).

Na elaboração do Mapa de Cobertura Vegetal e Uso do Solo foi utilizada imagem do software Google Earth-Pro (ano 2014), portanto as imagens utilizadas apresentam boa confiabilidade, tanto em relação aos dados obtidos em campo como em relação à resolução espacial. Após a definição das classes de cobertura vegetal e uso do solo as mesmas foram agrupadas em níveis de atividades

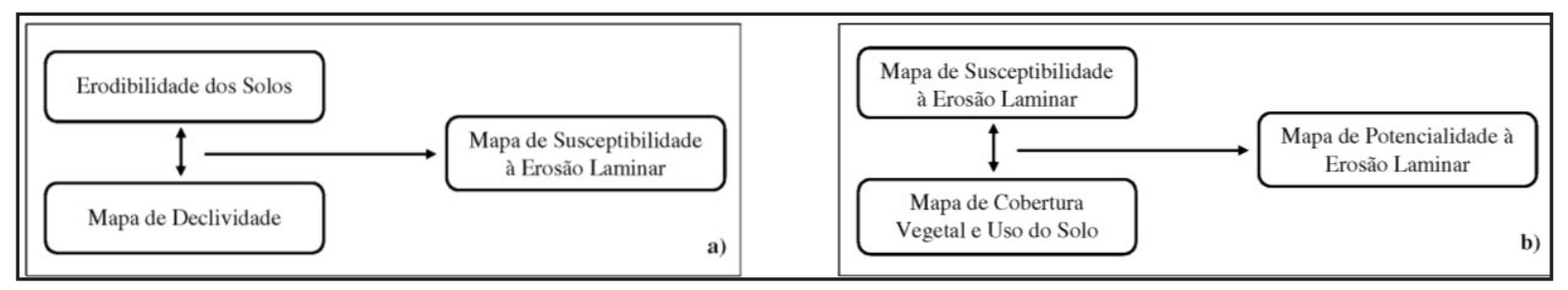

Figura 2 - Metodologia para elaboração dos mapas de susceptibilidade e de potencialidade à erosão laminar. Fonte: SALOMÃO (1992) 
Tabela 1 - Classes de declividade dos solos

\begin{tabular}{|c|c|}
\hline \hline Nome da classe & Declividade (\%) \\
\hline Plano & $0-3,0$ \\
\hline Suave ondulado & $3,1-8,0$ \\
\hline Moderadamente ondulado & $8,1-13,0$ \\
\hline Ondulado & $13,1-20,0$ \\
\hline Forte ondulado & $20,1-45,0$ \\
\hline Montanhoso ou escarpado & $>45,0$ \\
\hline
\end{tabular}

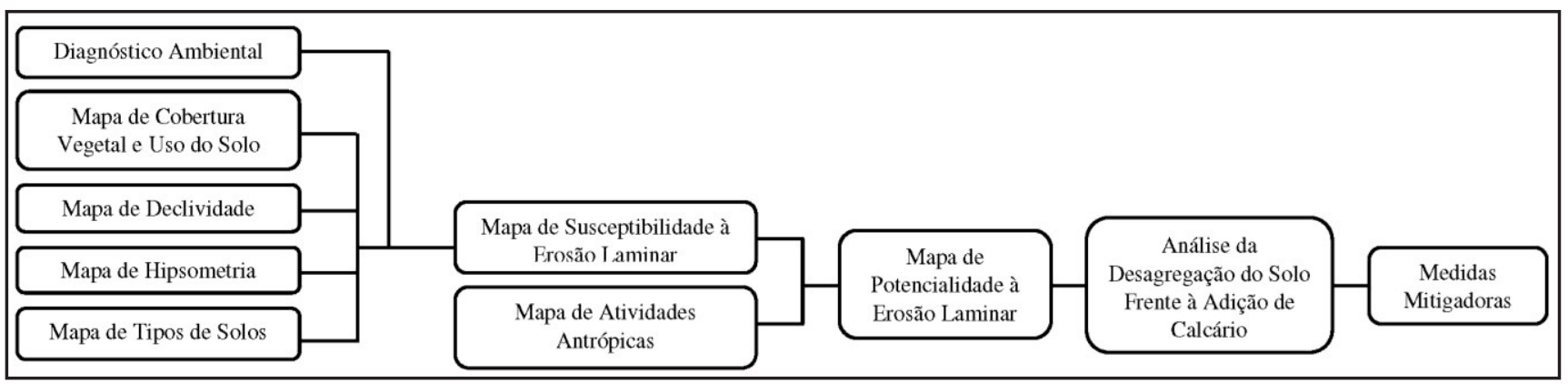

Figura 3 - Etapas do processo metodológico

Fonte: modificado SALOMÃO (1992)

antrópicas.

A metodologia utilizada no diagnóstico da área em estudo para a caracterização das classes de solos foi composta por parâmetros macroscópicos como cor, estrutura e textura. Não houve a realização de levantamento dos componentes químicos. Assim, os solos foram classificados nos três primeiros níveis categóricos do sistema de classificação da EMBRAPA/CNPS (2009) e do Manual Técnico de Pedologia do IBGE (2007).

A técnica de coleta de dados dos tipos de solos em campo baseou-se no Sistema de Informações Geográficas, onde houve a fotointerpretação de imagens do Google Earth-Pro (ano 2014), e o arquivo raster gerado por meio de dados altimétricos fornecidos pelos produtos TOPODATA/INPE (BRASIL, 2009). Esta mesma técnica foi utilizada para a elaboração da rede hidrográfica..

Para auxiliar a inspeção da vetorização em um primeiro momento foram utilizados como dados auxiliares: arquivo de drenagem na escala de 1:100.000, disponibilizado no site do Sistema Estadual de Estatísticas e de Informações Geográficas de Goiás (SIEG), modelo digital de terreno (SRTM) dos sistemas de projeção SIRGAS 2000 e SAD69 UTM, Fuso 22S.

$4^{\circ}$ - Avaliação da desagregação do solo frente à adição de calcário. Esta etapa foi realizada em duas partes: na primeira, duas provetas foram preenchidas com um litro de água destilada. Em uma foram inseridos $70 \mathrm{~g}$ de solo natural e na outra foram inseridos $70 \mathrm{~g}$ de solo natural e 20\% (14g) de calcário. Estas permaneceram em repouso por 24 horas. Na segunda parte do experimento foi realizado o mesmo procedimento anterior, contudo o solo utilizado foi desidratado após permanecer 24 horas na estufa. $5^{\circ}$ - Sugestão de possíveis medidas mitigadoras.

Todas as etapas do processo metodológico utilizado neste trabalho podem ser visualizadas na Figura 3, em forma de fluxograma.

\section{Resultados e discussões}

O diagnóstico ambiental baseou-se na Lei Complementar $\mathrm{N}^{\circ}$ 005, de 30 de Janeiro de 2002, do município de Aparecida de Goiânia, que dispõe sobre o zoneamento, uso e ocupação do solo, na área urbana e rural deste município e estabelece outras providências urbanísticas. Conforme esta lei a nascente do Córrego Almeida, situada no Bairro Jardim Luz, município de Aparecida de Goiânia (GO), corresponde a uma Área de Preservação Permanente localizada em Zona de Proteção Ambiental, ZPA-I (Figura 4).

Durante vistoria in loco foi constatada a existência de uma erosão do tipo voçoroca, consequência da má execução dos serviços de pavimentação das ruas da região vizinha e da implantação inadequada das redes de drenagem urbana. Percebe-se que as redes de águas pluviais são direcionadas à cabeceira do Córrego Almeida e que se apresentam parcialmente danificadas pelo excesso de escoamento (Figura 5a e Figura 5b).

A Figura 6 mostra o estágio avançado em que se encontra a erosão situada na Área de Preservação Permanente da nascente do Córrego Almeida. A (Figura 6a) mostra parte da erosão em frente ao ponto de lançamento das águas plu- 


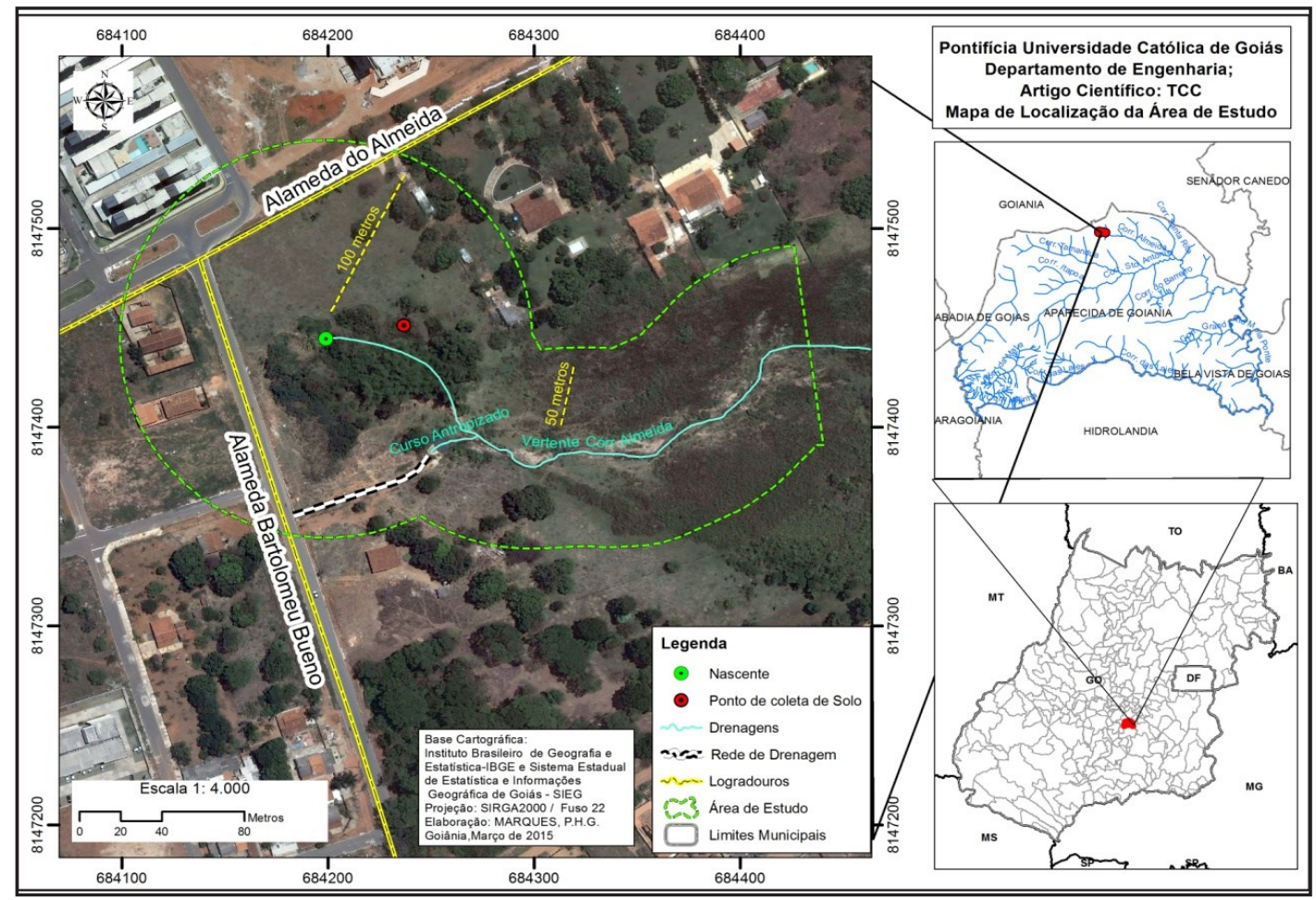

Figura 4 - Mapa de localização e pontos de interesse das areas de estudo
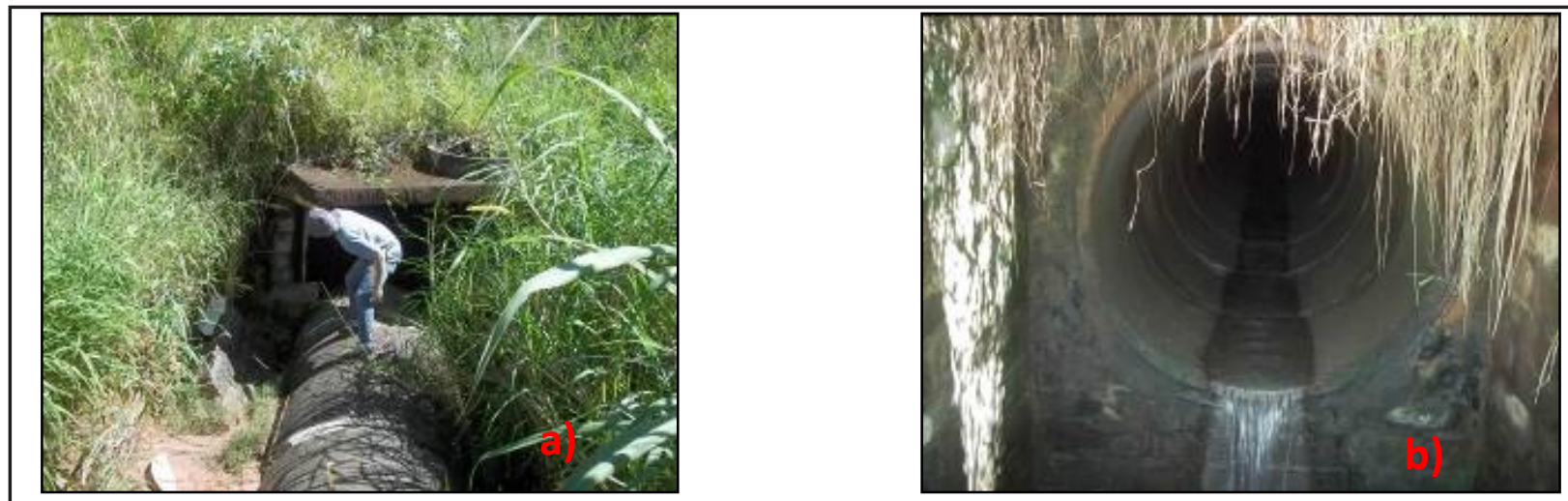

Figura 5 - Rede de drenagem descoberta devido à má execução de obras de engenharia

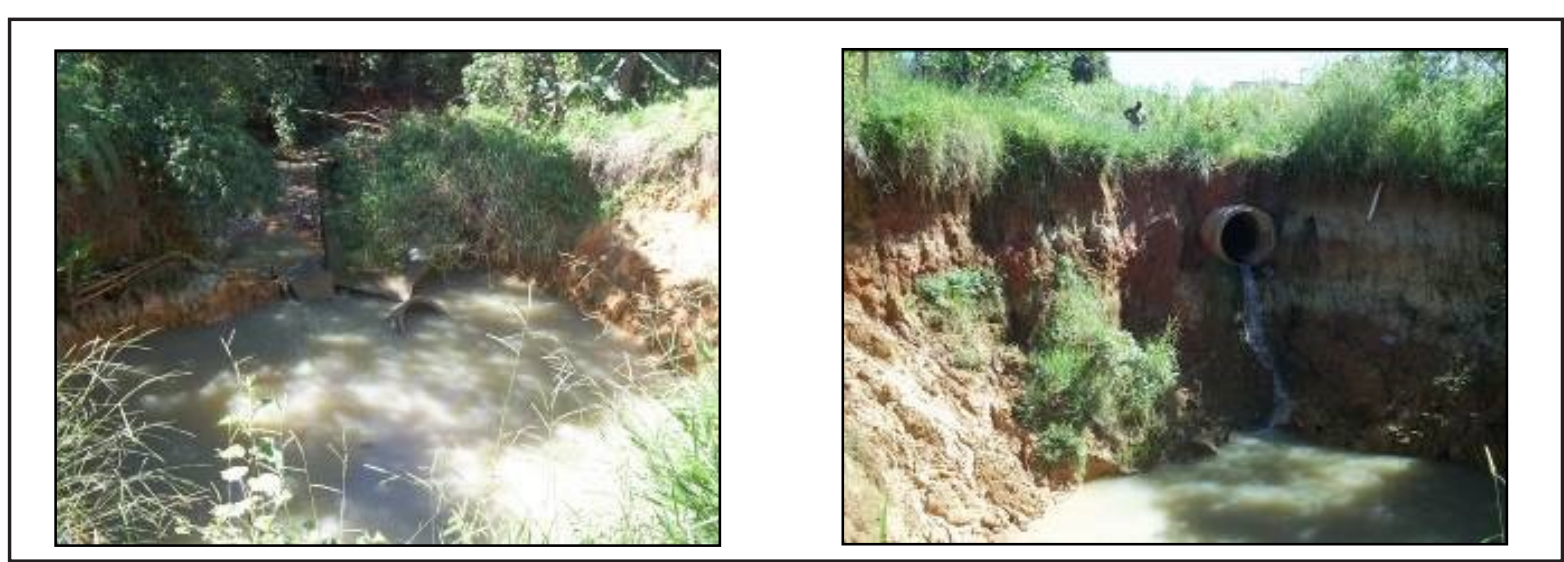

Figura 6 - Erosão em estágio avançado desencadeada por falta de dissipadores de energia e rompimento da rede de drenagem pluvial 
viais, enquanto a (Figura 6b) mostra a magnitude da erosão.

Com o resultado do trabalho de campo foi possível elaborar os mapas físicos. São eles: Cobertura Vegetal e Uso do Solo, Declividade, Hipsometria, Solos, Atividades Antrópicas, Susceptibilidade à Erosão Laminar e Potencialidade à Erosão Laminar.

Através do Mapa de Cobertura Vegetal e Uso do Solo (Figura 7) constata-se claramente o descumprimento da Lei Complementar $\mathrm{N}^{\circ}$ 005/2002, do município de Aparecida de Goiânia, em que não é permitida qualquer edificação, de caráter permanente, ou pavimentação marginal ao curso d'água. Como consequência das edificações houve a retirada de grande parte da cobertura vegetal nativa da área de preservação permanente.

Por meio da análise do Mapa de Declividade (Figura 8) percebe-se que a nascente do Córrego Almeida está bastante próxima do local de maior declividade da região, o que somado à baixa disponibilidade de espécies nativas e atividades antrópicas intensivas favorece o desenvolvimento do processo erosivo existente.

O mapa hipsométrico (Figura 9) foi gerado utilizandose o método de "quebras naturais" para a determinação dos intervalos na legenda, divididos em seis classes, o que permite visualizar melhor as irregularidades no padrão de distribuição das altitudes no terreno.

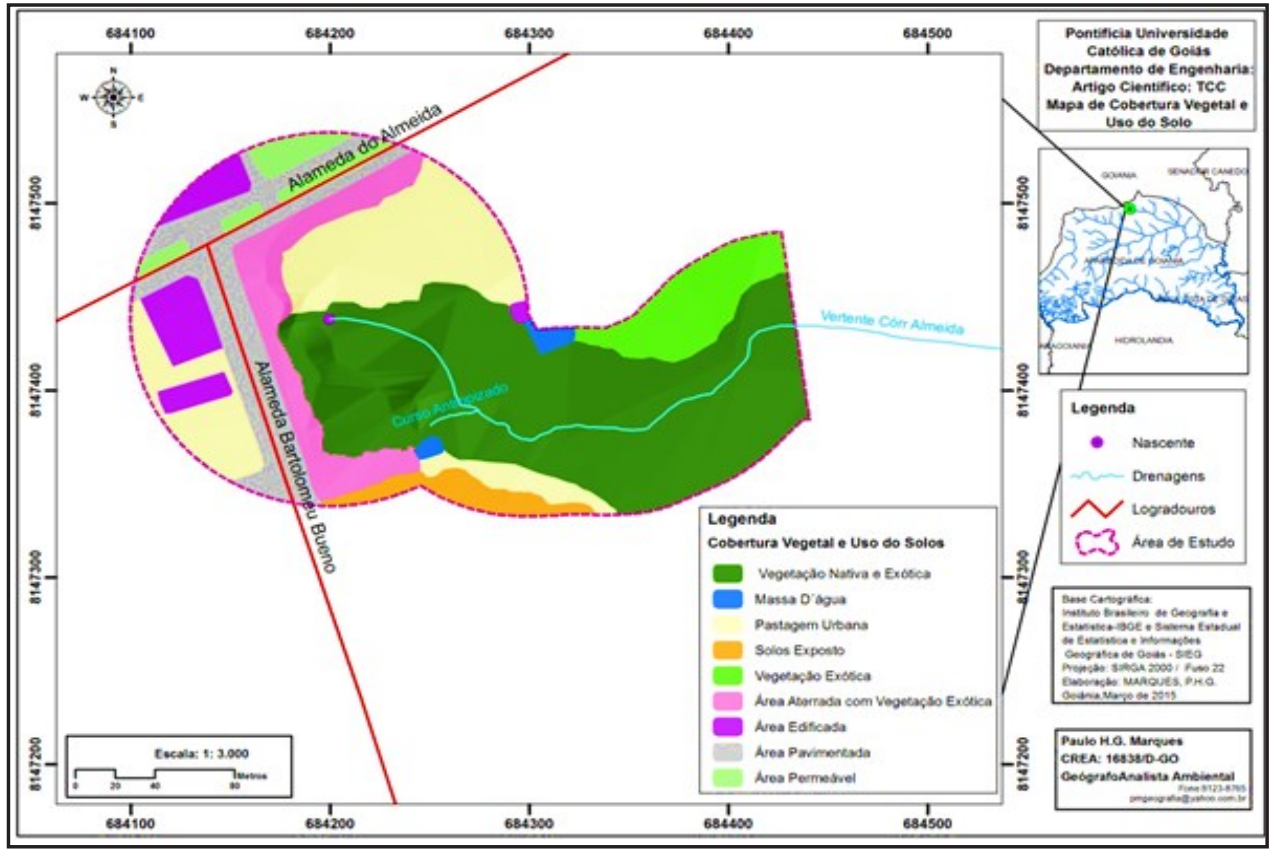

Figura 7 - Mapa de cobertura vegetal e uso do solo

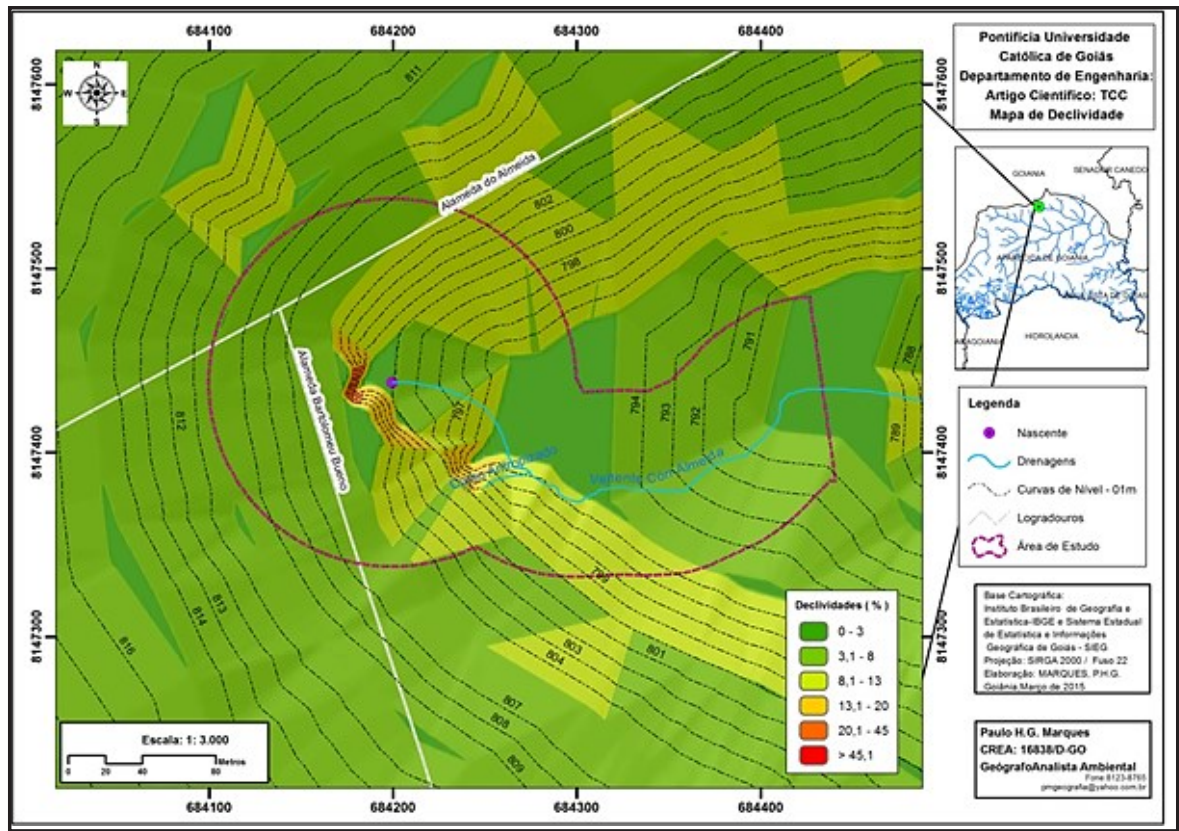

Figura 8 - Mapa de declividade 


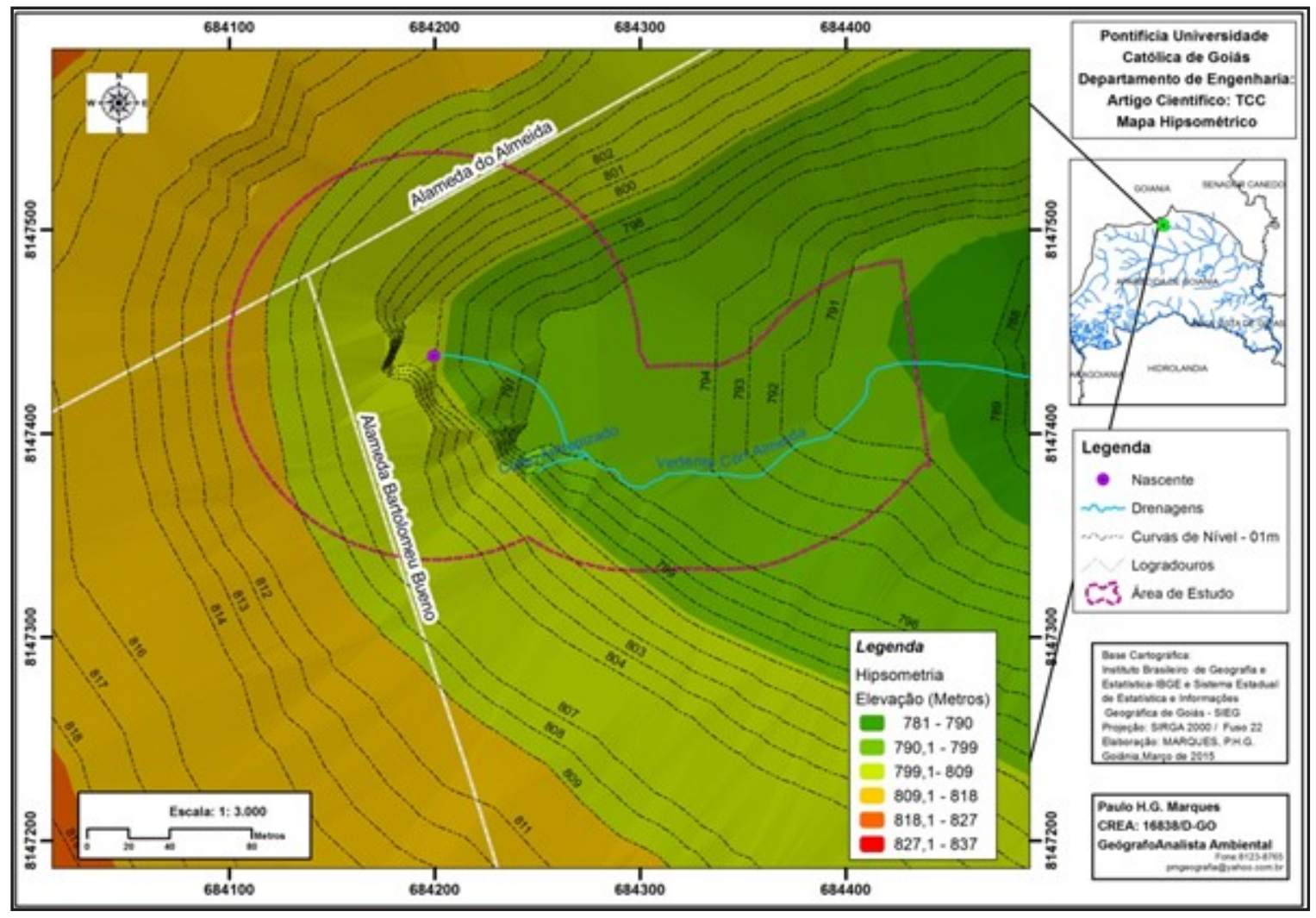

Figura 9 - Mapa hipsométrico

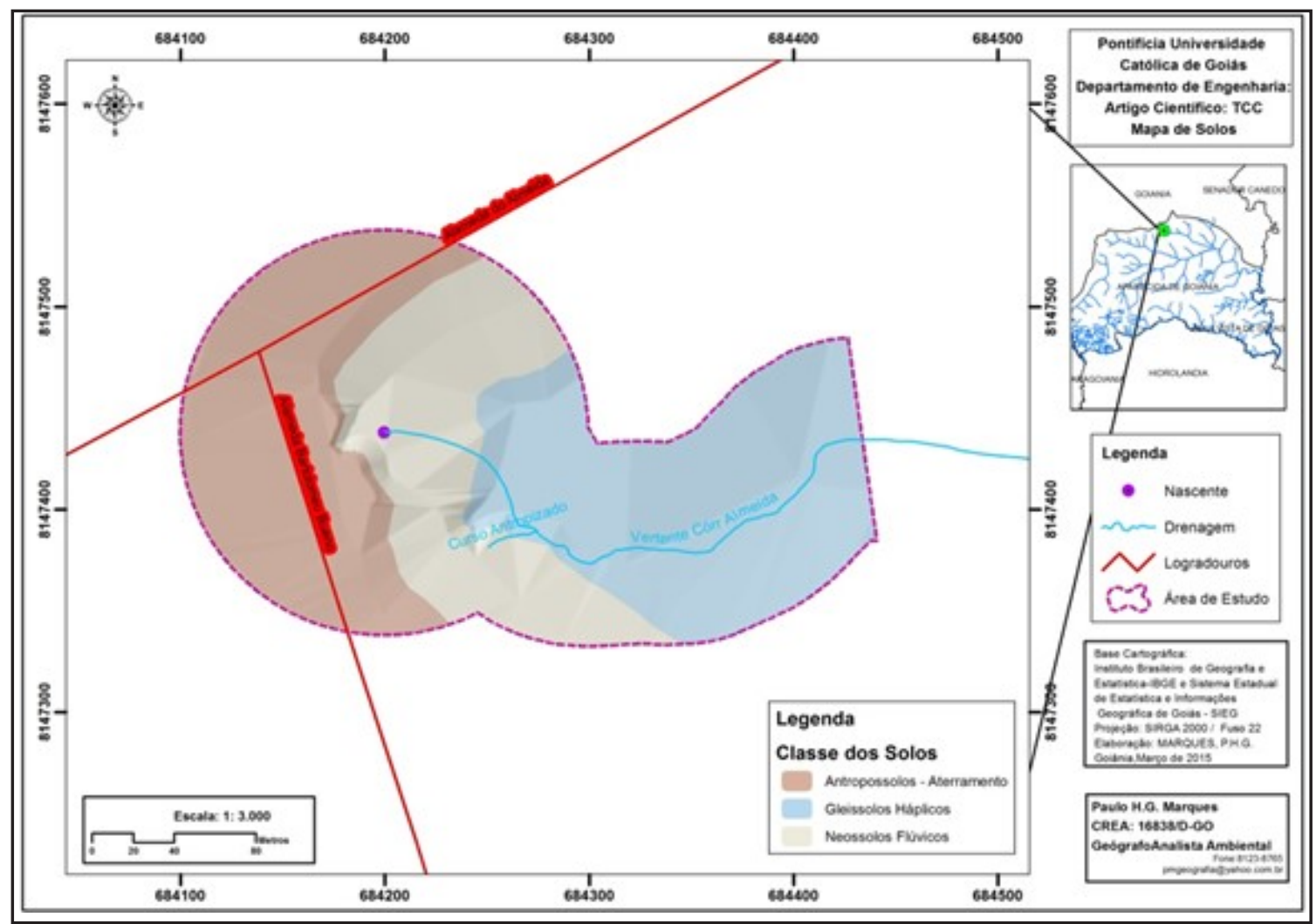

Figura 10 - Mapa dos tipos de solos 
A área em estudo possui apenas três variedades de solos: Antropossolos, Gleissolos Háplicos e Neossolos Litólicos, com associação de argissolos. Neste caso os antropossolos merecem destaque, pois foram formados em decorrência do aterro realizado pela prefeitura de Aparecida de Goiânia, com o uso de materiais inadequados para esta atividade (Figura 10). Os gleissolos são solos característicos de áreas alagadas ou sujeitas a alagamento. Já os Neossolos são solos pouco evoluídos constituídos por material mineral, ou por material orgânico com baixa espessura.

Para a elaboração do mapa de susceptibilidade à erosão laminar foram analisadas e utilizadas as classes de erodibilidade dos solos conforme indica a Tabela 2.Com a intersecção entre o mapa dos tipos de solos, as classes de erodibilidade e o mapa de declividade, obteve-se o mapa de susceptibilidade à erosão laminar (Tabela 3 e Figura 11), que apresenta o aspecto de erosão natural da área.
S1 - Extremamente susceptível: Compreende áreas onde predominam os antropossolos e neossolos, associados a declividades superiores a $20 \%$. Esta classe de susceptibilidade está situada na área aterrada com materiais inadequados.

S2 - Muito susceptível: Abrange áreas de solos do tipo antropossolos e neossolos, em relevos com declividades entre $12 \%$ e $20 \%$. Predominante na APP da nascente.

S3 - Moderadamente susceptível: Compreende as áreas de transição dos solos do tipo neossolo para gleissolo, com declividades entre $6 \%$ e $12 \%$. Ocorre principalmente na vertente próxima ao canal de drenagem da área de estudo.

S4 - Pouco susceptível: Ocorre na área com solo do tipo gleissolos, associada a declividades que variam de $0 \%$ a $6 \%$. Ocorre na parte leste da área de estudo, em relevos planos a suavemente ondulados.

Tabela 2 - Determinação das classes de erodibilidade (E) com base no tipo de solo

\begin{tabular}{|c|c|c|}
\hline $\begin{array}{c}\text { Classes de } \\
\text { erodibilidade }\end{array}$ & $\begin{array}{l}\text { Índices de erodibilidade } \\
\text { relativa }\end{array}$ & Classes de solo \\
\hline E1 & 8,1 a 10 & $\begin{array}{l}\text { Neossolos, Cambissolos, Plintossolos e Argissolos } \\
\text { de textura arenosa / média abruptos e Antropossolos }\end{array}$ \\
\hline E2 & 6,1 a 8,0 & $\begin{array}{c}\text { Latossolo Amarelo, Argissolos de textura média } \\
\text { argilosa }\end{array}$ \\
\hline E3 & 4,1 a 6,0 & $\begin{array}{l}\text { Latossolo Vermelho-Amarelo, Argissolos de } \\
\text { texturas argilosas }\end{array}$ \\
\hline E4 & 2,1 a 4,0 & Latossolo Vermelho e Nitossolos \\
\hline E5 & 0,0 a 2,0 & Gleissolos \\
\hline & & Fonte: SALOMÃO (1992 \\
\hline
\end{tabular}

Tabela 3 - Determinação das classes de susceptibilidade à erosão laminar da área de estudo

\begin{tabular}{|c|c|c|c|c|}
\hline \multirow{2}{*}{$\begin{array}{c}\text { Classes de } \\
\text { erodibilidade }\end{array}$} & \multicolumn{5}{|c|}{ Classes de isovalores de declividade (\%) } \\
\cline { 2 - 5 } & $\mathbf{2 0}$ & $\mathbf{1 2}$ a 20 & $\mathbf{6}$ a 12 & $\mathbf{0}$ a 6 \\
\hline E1 & $\mathrm{S} 1$ & $\mathrm{~S} 1$ & $\mathrm{~S} 2$ & $\mathrm{~S} 2$ \\
\hline $\mathrm{E} 2$ & $\mathrm{~S} 2$ & $\mathrm{~S} 2$ & $\mathrm{~S} 2$ & $\mathrm{~S} 3$ \\
\hline $\mathrm{E} 3$ & - & $\mathrm{S} 3$ & $\mathrm{~S} 3$ & $\mathrm{~S} 4$ \\
\hline E4 & - & $\mathrm{S} 4$ & $\mathrm{~S} 4$ & $\mathrm{~S} 5$ \\
\hline E5 & - & - & $\mathrm{S} 5$ & S5 \\
\hline
\end{tabular}




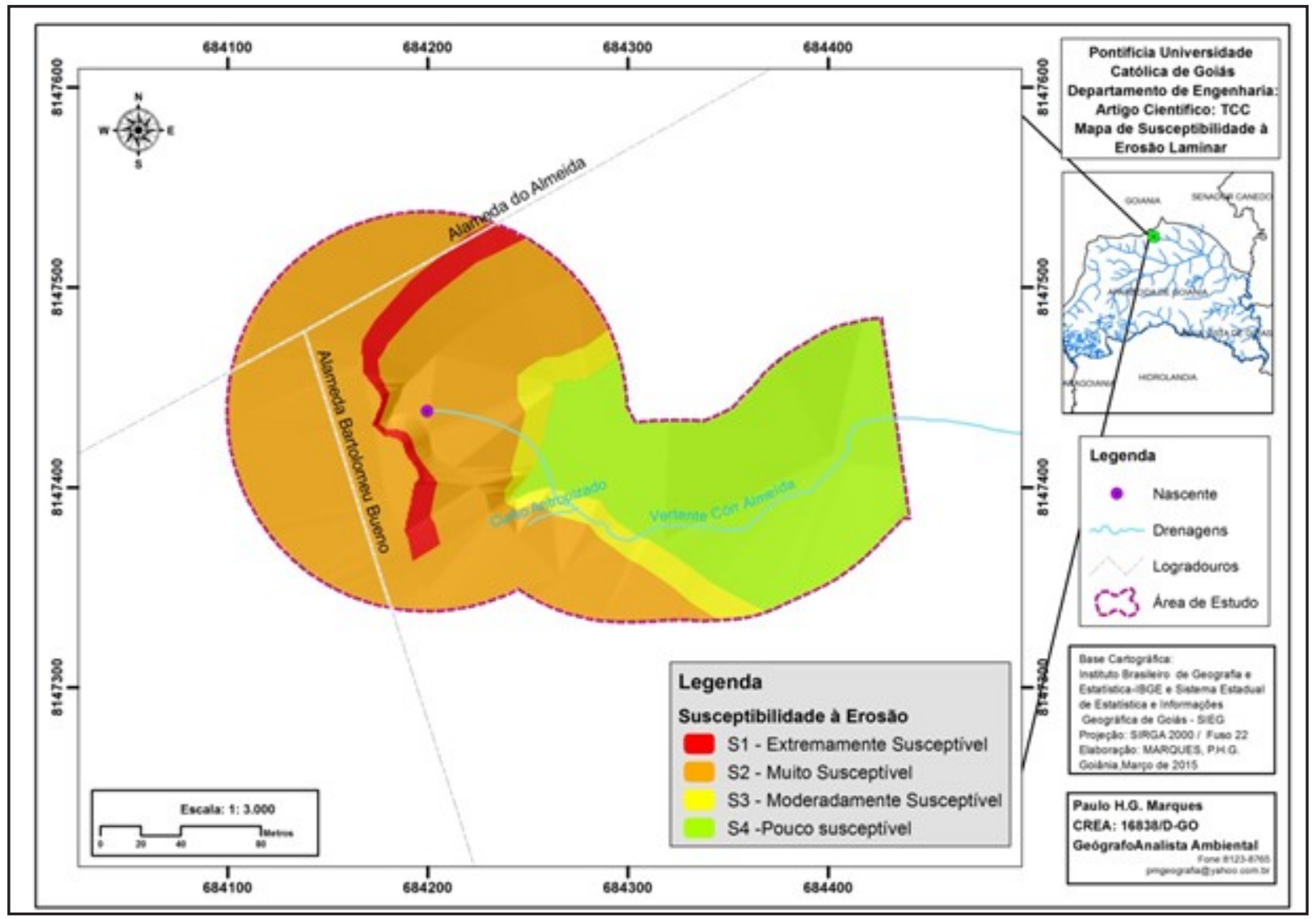

Figura 11 - Mapa de susceptibilidade à erosão laminar

Tabela 4 - Definição das classes de uso e cobertura vegetal do solo ante a erosão laminar

\begin{tabular}{|c|c|}
\hline Classe de uso ante a erosão laminar & Uso do solo / Cobertura vegetal \\
\hline Atividade antrópica intensiva & Áreas Urbanizadas \\
\hline Atividade antrópica moderada & Áreas Urbanizadas, Campos e pastagens. \\
\hline Atividade antrópica moderada a reduzida & Mata nativa e vegetação exótica \\
\hline
\end{tabular}

Quadro 1 - Definição das classes de potencial para erosão laminar

\begin{tabular}{|c|c|c|c|}
\hline \multirow{2}{*}{$\begin{array}{c}\text { Classe de } \\
\text { susceptibilidade à } \\
\text { erosão laminar }\end{array}$} & $\begin{array}{c}\text { Classes de uso e cobertura do solo ante a erosão laminar } \\
\text { Atividade antrópica } \\
\text { intensiva }\end{array}$ & $\begin{array}{c}\text { Atividade antrópica } \\
\text { moderada }\end{array}$ & $\begin{array}{c}\text { Atividade antrópica } \\
\text { moderada a reduzida }\end{array}$ \\
\hline S1 & PI & PI & PIII \\
\hline S2 & PI & PII & PIII \\
\hline S3 & PII & PII & PIII \\
\hline S4 & PII & PII & PIII \\
\hline S5 & PIII & PIII & Fonte: SALOMÃO (1992) \\
\hline
\end{tabular}


Após a elaboração do mapa de susceptibilidade à erosão laminar foi realizada a intersecção do mesmo com o mapa de atividades antrópicas (Tabela 4 e Figura 12).Na área de estudo foram identificadas atividades antrópicas intensiva, moderada e moderada a reduzida. Em razão do decapeamento da cobertura vegetal natural essas áreas são mais susceptíveis aos processos erosivos. Em relação à potencialidade para erosão laminar da área de estudo, foram definidas três classes, identificadas por algarismos romanos, variando de PI (maior potencialidade) a PIII (menor potencialidade) (Quadro 1).

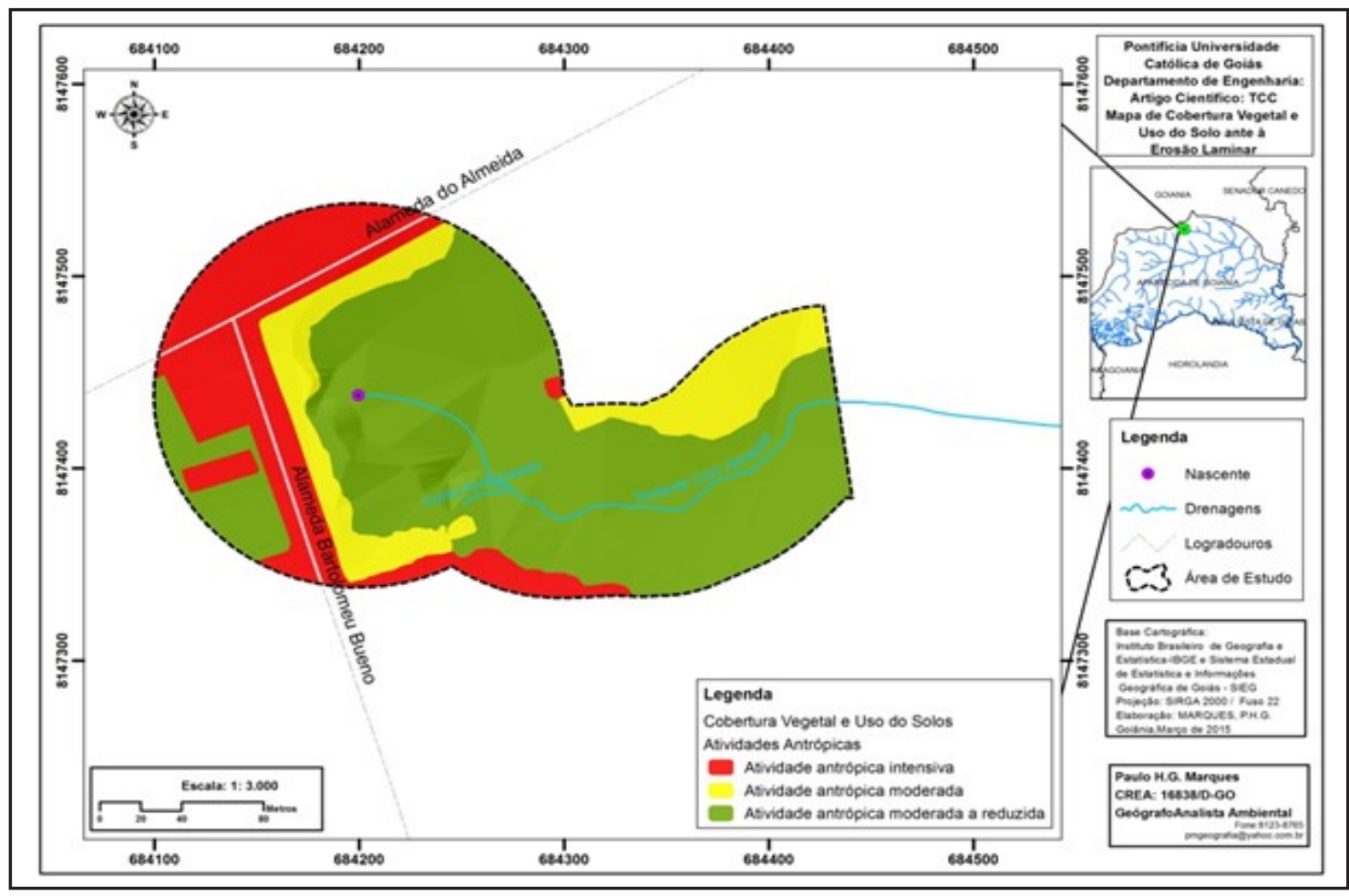

Figura 12 - Mapa de cobertura vegetal e uso do solo em relação à erosão laminar

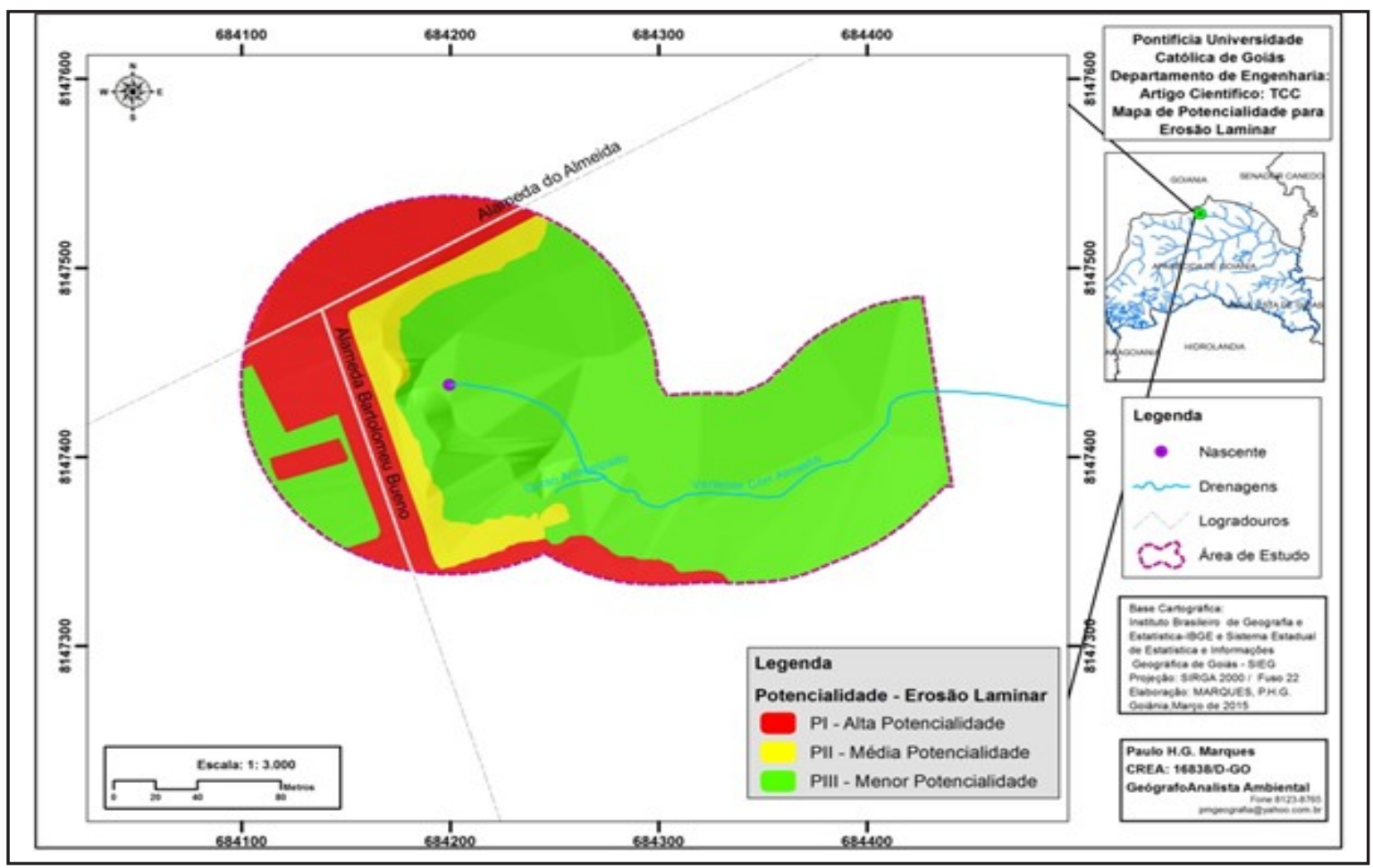

Figura 13 - Mapa de potencialidade à erosão laminar 
A susceptibilidade natural dos solos à erosão laminar, aliada aos diferentes usos, resulta em diferentes potencialidades para erosão. As áreas que passaram por processo de urbanização irregular são geradoras de degradação ambiental, sendo assim de alta susceptibilidade à erosão laminar, o que, consequentemente, resulta em alta potencialidade (Figura 13).

PI - Alta potencialidade: Verifica-se em áreas de susceptibilidade à erosão laminar extremamente alta, nas quais foram executadas obras de pavimentação das ruas e drenagem urbana de forma inadequada, edificação de prédios e residências e exposição do solo. Nas áreas de alta potencialidade à erosão laminar são esperados processos erosivos de difícil controle, associados ao uso incompatível do solo.

PII - Média potencialidade: Ocorre em áreas de alta susceptibilidade, onde o uso do solo é moderado ou muito reduzido, em áreas de média susceptibilidade com atividade antrópica moderada ou também em áreas de atividade antrópica intensiva em que a susceptibilidade é baixa. Neste caso trata-se da erosão existente e da área aterrada irregularmente pela prefeitura de Aparecida de
Goiânia, com vegetação exótica.

PIII - Menor potencialidade: Está presente em áreas nas quais predomina a vegetação natural remanescente ou áreas de baixa susceptibilidade, em que a atividade antrópica é moderada ou reduzida. A porção de menor potencialidade na área em estudo é composta pela vegetação nativa e pastagem urbana, com espécies exóticas.

\section{Desagregações do solo frente à adição de calcário}

Para avaliar parcialmente o comportamento estrutural do solo frente à adição de calcário (20\%) nos processos de desagregação/sedimentação realizou-se sugestivamente ensaios simples para avaliar o quanto o solo iria desagregar com a mistura. Esta ação visou verificar o quanto o comportamento do solo é influenciado pela adição de calcário na recomposição florística ou correção do pH para a execução das atividade do Plano de Recuperação de Áreas Degradadas (PRAD).

As Figuras 14 e 15 mostram duas provetas (1 e 2). Na Figura $14 a$, a proveta 1 possui $70 \mathrm{~g}$ de solo natural na presença de 1L (um litro) de água destilada e a proveta 2

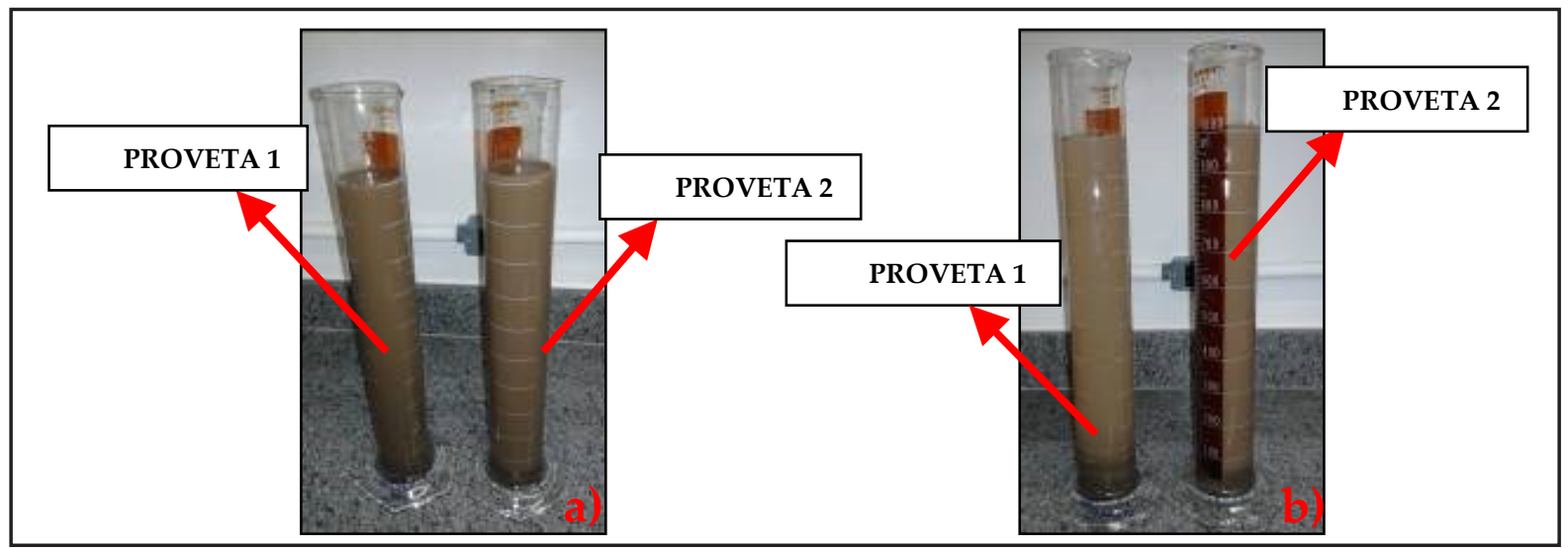

Figura 14 - Avaliação da desagregação do solo natural frente à adição de calcário

Na Figura $15 a$ a proveta 1 possui $70 \mathrm{~g}$ de solo seco na presença de $1 \mathrm{~L}$ (um litro) de água destilada e a proveta 2 contém 70g de solo seco na presença de $1 \mathrm{~L}$ (um litro) de água destilada, com a adição de $20 \%(14 \mathrm{~g})$ de calcário. A Figura $15 b$ ilustra o resultado do experimento para as mesmas provetas 1 e 2 após $24 \mathrm{~h}$ em repouso.

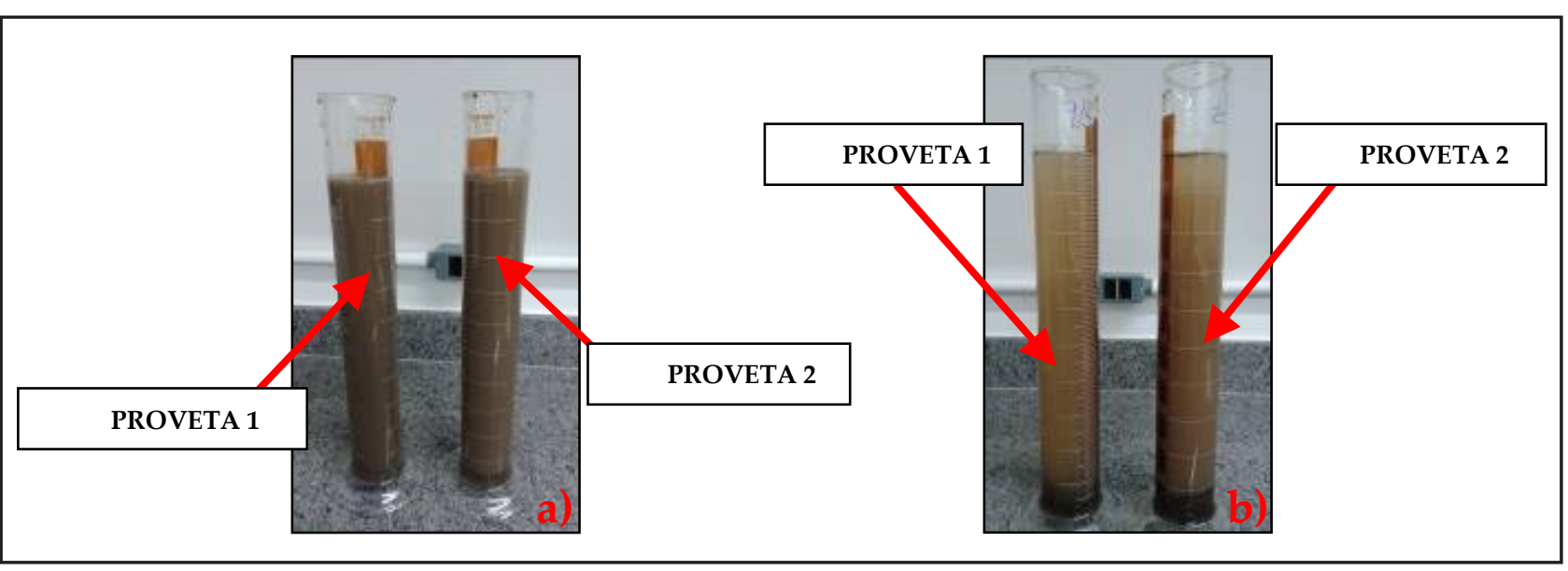

Figura 15 - Avaliação da desagregação do solo seco frente à adição de calcário 
contém $70 \mathrm{~g}$ de solo natural na presença de $1 \mathrm{~L}$ (um litro) de água destilada com a adição de $20 \%$ (14g) de calcário. A Figura $14 b$ ilustra o resultado do experimento para as mesmas provetas 1 e 2 após 24 h em repouso.

Após a realização dos experimentos percebeu-se que a adição do composto químico (calcário) no solo na proporção indicada afetou a estrutura do solo, ou seja, promoveu desagregação das partículas finas (desestabilizou o solo). Sem a adição deste tipo de calcário, a microestrutura do solo não seria afetada, a susceptibilidade à erosão é menor e algumas etapas para realização do PRAD no que tange a recomposição vegetal com a utilização de calcário utilizado poderia não ser indicada. Caso fosse utilizado, poderia tornar o processo erosivo mais acelerado. Quando o solo é seco, percebe-se que o solo não se desagrega tanto, melhorando um pouco as condições de estabilidade, porém, a desagregação ainda acontece.

\section{Conclusões}

O diagnóstico ambiental da área de preservação permanente da nascente do Córrego Almeida constatou-se que o principal impacto ambiental existente no local de estudo é a erosão do tipo voçoroca, possivelmente ocasionada pelo lançamento de grande volume e velocidade das águas pluviais no corpo receptor e pelo aterro para construção das vias urbanas em local com alto potencial erosivo (conforme mapas de susceptibilidade e potencialidade à erosão laminar).

Após elaboração e análise do Mapa de Potencialidade à Erosão Laminar nota-se que 68,9\% da área avaliada possuem menor potencialidade à erosão (predominância de vegetação natural remanescente ou áreas de baixa susceptibilidade), 22,6\% possuem alta potencialidade (áreas de susceptibilidade à erosão laminar extremamente alta onde ocorreram intervenções antrópicas) e 8,5\% possuem média potencialidade (área aterrada pela prefeitura de Aparecida de Goiânia para pavimentação de vias urbanas e redes de drenagem).

Como medida mitigadora sugere-se a elaboração e execução de um Plano de Recuperação de Área Degradada (PRAD) que contemple a recuperação da erosão encontrada, recomposição florística da área danificada (de preferência com espécies nativas) levando em consideração as características físicas, químicas e estruturais do solo local (solo tropical) e adequado dimensionamento da rede de drenagem pluvial, sistemas de lançamento e dissipação de energia.

Conclui-se também pelos ensaios de desagregação realizados, que o tipo e a concentração dos abubos (calcários) utilizados devem ser avaliados e previstos, pois, podem tanto ajudar na recomposição florística e recuperação da erosão (crescimento da vegetação nativa e posteriormente agregação do solo devido às raízes) ou acelerar o processo erosivo (desagregação química do solo).

Enfim, o trabalho demonstrou que a aplicação da metodologia apresentada por Salomão (1992), caso fosse utilizada como ferramenta de planejamento, poderia minimizar os impactos ambientais diagnosticados na área de preservação permanente, os quais ainda são influenciados pela urbanização. Para que os impactos ambientais sejam de menor magnitude, ou evitados, são necessários programas de educação ambiental e planejamento e controle das atividades antrópicas.

\section{Referências}

AÇÃO CIVIL PÚBLICA AMBIENTAL. Ministério Público do Estado de Goiás. $4^{\circ}$ Promotoria de Justiça de Aparecida de Goiânia, 2004. Disponível em <http://www.mpgo. mp.br/portalweb/hp/9/docs/microbacia_almeida.pdf $>$. Acesso em 04 de março de 2015.

ALVES, A. K.; COSTA, M. V. C. V. Mapeamento do Uso do Solo e Cobertura Vegetal da Bacia do Ribeirão Santa Juliana no Triângulo Mineiro - MG. In: Simpósio Brasileiro de Sensoriamento Remoto (SBSR), 13., 2007, Florianópolis. Anais... São José dos Campos: INPE, 2007. Artigos, p. 3.877-3.883. Disponível em:<http://marte.dpi.inpe.br/ col/dpi. inpe.br/sbsr@80/2006/11.15.21.21/doc/3877-3883. pdf $>$. Acesso em 26 de fevereiro de 2012.

ASHMAN, M. R.; PURI, G. Essential soil science: a clear and concise introduction to soil science. Oxford: Blackwell Publishers, 2002. 198 p.

BRASIL. Banco de Dados Geomorfométricos do Brasil (TOPODATA/INPE). 2009. Disponível em <http://www. dsr.inpe.br/topodata/>. Acesso em 06 de março de 2015.

CONSELHO NACIONAL DE MEIO AMBIENTE (CONAMA). Resolução n 302, de 20 de Março de 2002. Dispõe sobre os parâmetros, definições e limites de Áreas de Preservação Permanente de reservatórios artificiais e o regime de uso do entorno, 2002.

CARVALHO, J. C.; SALES, M. M.; SOUZA, N. M.; MELO, M. T. S. Processos Erosivos no Centro-Oeste Brasileiro. Brasília: Universidade de Brasília: FINATEC, 2006. XXXIV, 464 p.

CONCIANI, W. Processos Erosivos: Conceitos e Ações de Controle. Cuiabá: CEFET-MT, 2008, 148p.

EMPRESA BRASILEIRA DE PESQUISA AGROPECUÁRIA. Centro Nacional de Pesquisa de Solos. Sistema brasileiro de classificação de solos. Rio de Janeiro, 2009. 412 p. 
FRANCO, J. G. O. Direito Ambiental Mata Ciliares. Curitiba: Juruá, 2009.

GUERRA, S. M. S. Carta de predisposição à erosão na SUAPE, $P E$. Congresso Brasileiro de Geologia de Engenharia, $9^{\circ}$, Anais digitais. 1999.

INSTITUTO BRASILEIRO DE GEOGRAFIA E ESTATÍSTICA (IBGE). Zoneamento Ecológico Econômico da Área do Aglomerado Urbano de Goiânia. Goiânia, 1994.

Manuais Técnicos em Geociências. Manual Técnico de Pedologia. Divulga os procedimentos metodológicos utilizados nos estudos e pesquisas de geociências. Rio de Janeiro, RJ - Brasil, 2007. Disponível em <http://www.cidades.ibge.gov.br/painel/ historico. php? Lang=\&codmun=52014 0\&search= $\mid$ apareapar-deGoiânia>. Acesso em março de 2015.

. Estimativas da população residente no Brasil e unidades da federação com data de referência em $1^{o}$ de julho de 2014. Brasil, 2014. Disponível em <ftp://ftp.ibge. gov.br/Estimativas_de_Populacao/Estimativas_2014/ estimativa_dou_2014.pdf $>$. Acesso em março de 2015.

INFANTI JÚNIOR, N.; FORNASSARI FILHO, N. Processos da dinâmica superficial. In Geologia de Engenharia, ed. Antônio Manoel dos Santos e Sérgio Nertan Alves Brito. São Paulo: ABGE. p 132 - 152. 1998.

INSTITUTO DE PESQUISAS TECNOLÓGICAS (IPT) Manual de Geotecnia: Taludes de rodovias. Orientação para diagnóstico e solução de seus problemas. São Paulo: IPT. Publicação IPT no 1843. 388p, 1991.

LAL, R.; ELLIOT, W. Erodibility and erosivity. soil erosion research methods. 2 ed. Flórida: St. Lucie Press, USA, p. $181-208,1994$.

MARQUES, P. H. G. A Produção de Lixo (Resíduos) no Espaço Urbano de Goiânia: O Papel da Educação Ambiental. Goiânia, GO: UCG, 2006.

MOREIRA, I.V.D. Vocabulário Básico do meio ambiente. Rio de Janeiro: Feema/Petrobrás, 1992.

MOTA, S. Urbanização e meio ambiente. 3 ed. Rio de Janeiro: ABES, 2003, 356 p.

NASCIMENTO, M. A. L. S.; CASSETI, V. Carta geomorfológica do município de Goiânia. In: Carta de Risco do Município de Goiânia. IPLAN/IBGE/UFG, Goiânia, 1991.

NBR ISO 14.001 - Sistemas da gestão ambiental: requisitos com orientação para uso. Rio de Janeiro: ABNT, 2004.
GOIÂNIA. Carta de Risco de Aparecida de Goiânia - GO. Relatório Final. Goiânia, Goiás, 2012.

PRUSKI, F. F. Conservação do Solo: práticas mecânicas para controle da erosão hídrica. 2. ed. atual. e ampl. - Viçosa: Ed. UFV, 2009, 279 p.

SALOMÃO, F.X.T. Controle e prevenção dos processos erosivos. In: GUERRA et. al. Erosão e conservação dos solos: conceitos, temas e aplicações. 1999. Rio de Janeiro: Bertrand Brasil, Cap. 7, p.229-267.

Erosão e a ocupação rural e urbana. In: 3ํㅡㄹ Curso de Geologia de Engenharia Aplicada a Problemas Ambientais. São Paulo: AGAMA-DIGEM, 1992. p. 44-71.

Subsídio para controle de erosão em Mato Grosso. Simpósio Nacional de Controle de Erosão, 6 Presidente Prudente. Anais digitais. 1998.

SANTANA, M. N. R. Identificação dos impactos ambientais da ocupação irregular na área de preservação permanente (APP) do Córrego Tamanduá em Aparecida de Goiânia. Anais do II Congresso Brasileiro de Gestão Ambiental 06 a 09 de novembro de 2011. Londrina - PR.

SEIXAS, B. L. S. Fundamentos do manejo e da conservação do solo. Salvador: Centro Editorial e Didático da UFBA, 1984, 304 p.

SOUSA, S. B.; PINHEIRO, E. S.; OLIVEIRA, L. C. N. Geoprocessamento e Geomorfologia Ambiental - Aplicações em análise de paisagem. In: $4^{\circ}$ Encontro Nacional dos Grupos PET Geografia, 2009, Três Lagoas - MS. Os paradigmas da geografia (re) pensando o território e o ambiente no ensino, pesquisa e extensão, 2009.

WILD, A. Soils and the environment: an introduction. Cambridge: Cambridge University Press, 1993. 287 p. 